\title{
Agricultural Value Chains and Smallholder Producer Relations in the CONTEXT OF SUPERMARKET CHAIN Proliferation in Southern AFrica
}

\author{
Chiedza L. Muchopa ${ }^{1}$ \\ ${ }^{1}$ Department of Agricultural Economics, University of Limpopo,Polokwane, South \\ Africa
}

\begin{abstract}
Access to regional markets by small scale producers remains a problem in Southern Africa, yet retailing is becoming big business. A proliferation of supermarkets has been witnessed since the 1990s with South Africa's Shoprite supermarket becoming a major player in African markets. Supermarkets play a critical role of food systems development in Southern Africa but theissues of concern pertain to how increased aggregate value can be generated for agricultural produce whilst at the same time retaining more value nationally/locally for smallholder agricultural producers. This paper focuses on small producers, characterising food systems evolution in Southern Africa and highlighting how small producers are relating with supermarkets. Drawing on existing empirical work to examine successful agribusiness initiatives for smallholder farmers in Africa in accessing regional value chains, the paper argues that ineffective regional policies contribute to forces preventing upgrading of smallholder farmers into regional markets. An analysis that synthesises various emerging issues regarding the relations between supermarkets and small producers is presented to inform research themes for uptake into policy formulation.
\end{abstract}

\section{KEYWORDS}

Agricultural value chain, Supermarkets, Smallholder producers, Africa, SADC, Policy

\section{INTRODUCTION}

Supermarkets are a central link to ensuring the growth of agricultural produce and food markets as well as ensuring the continued contribution to the livelihoods of small producers in the SADC region. It is therefore imperative that most of the small producers get access to supermarkets as an outlet for their marketed produce. At the first link of the agricultural value chain is a connection to production, such that the quality of produce has implications for the ability of small scale producers' access to markets. The nature of the first link of the agricultural value chain ultimately determines the type of markets that small producers can access, whether it will be the traditional markets or modern supermarket chains. In recent years there have been many initiatives put in place to address agricultural value chain problems affecting especially smallholder farmers in Africa[1]. Judging from the available literature[2] the processes are evidently more developed in Eastern Africa when compared to the level of progress and intervention in Southern Africa. The priority of agriculture and food security is high on the agenda in the SADC region and if food security is to be achieved, efficiency improvements in the marketing systems and value chains for agricultural produce are needed. There is notably an increased awareness from various stakeholders with regard to the importance of regional agricultural value chains. The issues raised in this paper are focused on cross cutting issues for the value chains in which small producers participate. 
South Africa leads in Southern Africa in terms of supermarket chain foreign direct investment (FDI) where investments in opening new stores in a selected few SADC host countries has been increasing in recent years as illustrated in Table 1 for the two leading South African supermarkets. The data presented shows the number of countries where South African supermarkets have been opened.A faster proliferation of supermarkets as experienced from the year 2002 should ideally also translate into increased access to markets for small producers in the SADC region. However,some studies[3], [4], [1] have alluded to the fact that the distribution of income along the value chains is skewed away from benefiting small producers. This phenomenon has been attributed to the lead firms/retailers determining the producers that will receive more value added by handpicking them to participate. Temu and Temu[5]note that traditionally small producers operated alongside supermarket chains and the small producers commanded larger market shares offering lower prices to the consumers. Whilst smallholder producers have the ability to integrate fully in value chains for identified chains like horticulture, dairy and traditional exports, Louw et al[6] have described the transformation of agricultural markets in Africa as erratic against the background of major supermarkets entering the markets. Vink et al[7]alluded to the process of "Shopritesation" referring to what some quarters have termed an invasion into the SADC by South African supermarkets, as a positive effect towards the development of local farming in South Africa.

Recent literature[8]; [9]; [10]; [11]converge in putting forward the argument that a response to consumer needs is the main driver in the supermarket chains directing the distribution of value added as producers are trying to meet specific consumer needs. Most of the small producers face greater constraints in meeting the required grades and standards. There is a general consensus regarding the need for engagement of the private sector in the development of the marketing system for the benefit of small producers. A dilemma however arises due to the fact that small producer characteristics determine the nature of engagement in business with the private sector. The small producers have a comparative disadvantage at the level of meeting the needs of the supermarket chains and thus they get sidelined. The eventual results seem to point to the fact that small producers somewhat become the losers fromefforts that may be forged towards the promotion of private sector involvement. The issues discussed in this paper are an initial analysis towards fleshing out the critical emerging issues and constraints regarding the development of regional agricultural value chains which at best are currently represented through supermarket chains being developed in Southern Africa.

\section{AcCess to Regional Value Chains}

South Africa has notably dominated the production of most agricultural produce in the SADC.In 2009, South African supermarkets accounted for $85 \%$ of the share of supermarkets in the SADC region according to calculations presented by Emongor and Kirsten [12]. Given South Africa's production dominance the country tends to be more dominant in the supply chains with agribusinesses that are more developed and specialized especially to supply the supermarkets. It is no surprise therefore that most of the agribusinesses in Southern Africa are lagging behind South Africa in levels of development. The South African economy is arguably dominating the SADC region mainly as a source of foreign direct investment flow into value chains as the supermarkets continue an expansion in the region.Shoprite supermarket currently has a presence in 17 African countries compared to 9 countries for Pick n Pay supermarket. In terms of the number of stores, Shoprite has 144 compared to 94 for Pick n Pay in Africa as of the year 2012.

Several researchers have contributed research that enables an analysis of the extent to which supermarkets in the SADC region have dictated the level of access to participation in the regional agricultural value chains especially for the small producers. Satisfying the needs of consumers is of paramount importance and access to consumer markets would enable smallholder farmers to gain the value from their production. Smallholder producers however are faced with stiff 
competition from agribusinesses in supplying consumers. Agribusinesses have preferential access to the markets as they are considered more reputable than individual farmers. This scenario has effectively contributed to reduced participation of small producers in supermarket chainsand therefore not easing the access to regional agricultural value chains.

Given that the domestic markets for most countries in Africa are small it is increasingly important that access to regional market access be is augmented. The South African supermarkets operating in SADC have engaged in some processes targeted at market augmentation. Pick n Pay for example has engaged in the facilitation of exports of Zambian sweet potatoes onto South African shelves by engaging roughly 64 small and large scale producers. Whilst this is a positive opportunity seeking to expand the market outlets for Zambian farmers it merely seems a token given that only a small number of farmers are participating. This is one clear demonstration of the benefits of developing regional agricultural value chains as producers are presented an opportunity able to tap into accessing distant markets. Shoprite reports that as part of its corporate citizen program they have fresh produce growing programmes with 456 local farmers in South Africa, and a Greenfields initiative which supports 167 small farmers [13]. On the one hand Pick $\mathrm{n}$ Pay submits that in Zambia, 70\% of their fruits and vegetables are produced in Zambia whilst the remaining 30\% is imported from South Africa[14].

\subsection{Value Chain Participation Frustrations for Small Producers}

Consistently smallholder farmers have dominated discussions and debates regarding access to consumer markets and the retailing effects on agricultural production. The more reliant markets for smallholder farmers are the fresh produce markets yet the smallholder farmers do not meet the required standards for supermarkets to accept their produce. Production contracts are in place for some farmers which enable strict monitoring of production standards and eases the ability of farmers to access the markets by addressing information asymmetries. There are varying degrees of growth and proliferation of supermarketsin the different countries within SADC hence the way in which small farmers are able to access producer markets vary. Multiple factors as presented in Table 1 can be isolated to differentiate varying degrees to which supermarkets in the SADC are able to absorb small producers as compared to the traditional role that was played by small producers in successfully satisfying the consumers.

Table 1. Basic Facts - Participation in value chains by small producers.

\begin{tabular}{|c|c|}
\hline Traditional & Supermarkets \\
\hline $\begin{array}{l}\text { Low costs maintained due to cheaper } \\
\text { linkages between traders and small } \\
\text { producers } \\
\text { Close proximity to consumers enabling } \\
\text { management of supplies } \\
\text { Frequent small supplies most suitable for } \\
\text { the low income urban dwellers } \\
\text { Unprocessed products }\end{array}$ & $\begin{array}{l}\text { Large procurement volume requirements } \\
\text { Poor access to value chain networks } \\
\text { Transactions costs are high } \\
\text { Payments for supplies not always instant, } \\
\text { can take one to two months which is not } \\
\text { attractive for small producers }\end{array}$ \\
\hline
\end{tabular}

The small producers are sidelined due to the need by supermarkets for large procurement volumes and coordination of activities in the value chain which is mostly lacking for the small produce networks. This has largely marginalized the small producers limiting the extent of benefits from supermarket chains. As noted by Louw et al [6], limited business skills, poor access to transport networks, dispersion of farms and lack of market information are among the factors contributing 
to the inability of small producers to take advantage of the growth in supermarket chains and networks in Southern Africa. Requirements for constant supply and high transactions costs prevent supermarkets from engaging in value chain activities of sourcing from small producers. Available evidence supports this observation as South African supermarkets operating in host African countries are reported to source their produce from South African farmers who produce and supply bulk to all their stores. Small producers in supermarket host countries are unable to compete with South African producers. Due to these emerging trends, small producers do not only compete with other large producers in their own countries but have to face competition from across national borders where in some instances their competitors are subsidized. The markets have also become concentrated resulting in supermarkets having greater market power and the small producers in weak bargaining positions.

The underlying question regards consumers' choice on whether to purchase from supermarkets or directly from farmers and what type of competition dynamics this has caused in regional agricultural value chains. Traditionally small producers have been producing surpluses which they marketed to the urban population but the proliferation of supermarkets is envisaged as being in direct competition with the traditional markets for small producers as urban consumers depend more on the supermarkets for their fresh produce who are able to offer them lower prices due to scale economies. This notion is supported by results from Emongor and Kirsten [12]showing that in Zambia, Botswana and Namibia the supermarkets import about $80 \%$ of their produce from South Africa and this in addition presents competition to small producers in those importing countries. It is expected that proliferation of supermarkets would boost local and national development for small producers yet the available evidence shows that whilst South Africa for example is investing in supermarkets in other SADC countries the greater portion of fresh produce in being sourced from South Africa. A further examination of the value chain participants shows that South African exported produce to the supermarkets in SADC is not from small producers. The small producers in South Africa are also hindered by difficulties in meeting standards and the quality dictated by the supermarkets locally within South Africa.

Technological, financial and organizational demands that the small producers face in dealing with accessing supermarkets are having major impacts on access to markets by smallholder farmers. A consideration of these factors immediately shows that the red light for inaccessibility to markets is firmly switched on, leaving little room for small producers to benefit. Will the rise of supermarkets promote competition levels that drive out small producers completely, leading to a loss of livelihoods? The rise of supermarkets need not lead to loss of livelihoods given that there are various ways in which to ensure the participation of small producers. There are however some challenges having a demand-driven approach that would serve the needs of and benefits small producers.

\subsection{Characterisation of Supermarket Value Chain Connections with Small Producers}

The literature on value chains for agricultural food and commodities suggests that the major challenge for small producers in Southern Africa is at the first link of the chain. The development of the value chains initiated through supermarketchain proliferation is to some extent excluding small producers from accessing markets at the SADC regional level because the participation environment is not enabling[15]. Thelack of competitivenessespecially in terms of quality and standards is a major constraint for the small producers. The common and minimum standards/requirements for produce supplied to supermarkets have been described in many case studies asa hindrance to participation in the agricultural value chains $[4,5,12]$. The long supply chains due to distances between South Africa and the supermarket chain host countries have tended to work in favour of local producers in certain cases as produce is locally sourced from supermarket host countries to avoid logistical hitches. A recognition of which countries are the powers in as far as the participation and organization of smallholders in value chains gives insight 
into how the farmers are organized and the representation at regional level. Barrett et al, [16]have presented evidence of how in Mozambique contract farming arrangements have proven an asset in addressing the issue of produce quality, grading and standards that hinder the participation levels of small producers in regional agricultural value chains.

Many studies concur that the lack of integration of small producers into regional agricultural value chains is as a result of high transactions costs, leading to costly participation by small producers. The demand-driven approach focuses on the retail and as such the driving force to access supermarkets is definitely outside the control of small producers as the trend towards procurement systems that favour supermarkets increasingly impacts negatively on the small producers. In some instances the trends towards small producer exclusion is attributed to consumer demands that are changing as urbanization and consumer income demographics change.The small producers are unable to participate equitably with possible loss of livelihoods in the face of proliferation of supermarkets. According to Louw et al [4], new procurement systems in use by supermarkets in South Africa are centered on centralization of procurement working with fewer suppliers, cross border sourcing networks, specialized wholesalers and use of private safety standards. The results are that there are shorter chains leaving little or no role for the small producers.

Two most common problems hindering the access to supermarkets can be isolated as the inability to supply constantly the required quantities and the quality and standards imposed for the produce. The bar has been set high for grades and standards of produce that can be admitted into the supermarkets. Small producers characteristically always face difficulties in accessing these markets as they are unable to meet the standards. There are also problems of fragmentation given that the smallholder farmers are dispersed in wide geographical areas leading to the inability to meaningfully aggregate produce to meet supermarket required quantities. Financing issues and lack of established businesses also top the problems in participating in supermarket chains as well as the lack of profitability especially for small producers[17]; [7]. This has generally led to which leads to a collapse of value chains. Supermarkets diffusion has brought changes to ways in which small producers can access retail markets. It has also been noted that access to supermarket chains by small producers enable them to reach higher levels of welfare equilibrium partly induced via their relationship with supermarket chains [16]. However, a simplified general problem tree as presented in Figure 1 can be generated as a reflection of the observations from literature enables the identification of some inherent problems working against welfare improvements for small producers. The general problem tree analysis identifies the small producers' competitiveness problem in supermarket chains which lead to low incomes.

There is broad consensus that small producers are not competitive in supermarket chains. The small scale producers' problem is perpetuated by their vulnerability that exposes them to face greater risks of non-payment resulting from inability to meet the supermarket required quality and standards of produce. High upfront investments are also required by small producers to enable them to sustain participation in agricultural value chains.

\subsection{Observed Socio-Economic Impacts of Supermarket Chain Proliferation on Small Producers in Selected Countries}

Table 2 sets out some of the observed impacts on identified winners and losers from the proliferation of supermarkets in SADC. To support the notion that supermarket chain proliferation can potentially have a negative socio-economic impact on small producers, data from a food security research project in Zambia, showed that 39\% of total household cash income for small producers in selected towns in Zambia is from fresh produce sales. The fresh produce is channeled predominantly through traditional markets (above 95\%) and the rest through the 
modern system of supermarkets [18]. This potentially means a loss of livelihoods will result from a displacement of traditional markets by modern supermarkets.

Table 2.Winners and losers from proliferation of supermarkets in SADC.

\begin{tabular}{|c|c|c|}
\hline \multicolumn{2}{|r|}{ CATEGORY } & WHY AND HOW \\
\hline$\frac{\mathscr{c}}{\mathbf{c}}$ & $\begin{array}{l}\text { Foreign owned supermarkets } \\
\text { sourcing locally or regionally } \\
\text { Large independently owned fresh } \\
\text { produce farms } \\
\text { Small producers intricately linked } \\
\text { with wholesale distributors in the } \\
\text { agricultural value chains }\end{array}$ & $\begin{array}{l}\text { Foreign owned supermarkets committed to } \\
\text { satisfy customers by providing quality } \\
\text { produce of specified standards as well as } \\
\text { ensuring constant supplies. } \\
\text { Small producers and large producers will } \\
\text { benefit if intricately linked through collective } \\
\text { action and contracting arrangements with the } \\
\text { supermarket distribution system. }\end{array}$ \\
\hline 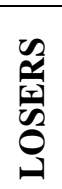 & $\begin{array}{l}\text { Small producers } \\
\text { Local supermarkets with no } \\
\text { foreign investment }\end{array}$ & $\begin{array}{l}\text { Small producers not linked to the supermarket } \\
\text { and outside the networks will not benefit } \\
\text { mainly due to the inability to meet stricter and } \\
\text { sophisticated required standards. }\end{array}$ \\
\hline 是 & $\begin{array}{l}\text { Producers both large and small } \\
\text { competing with imported fresh } \\
\text { produce } \\
\text { Distributors and local } \\
\text { wholesalers being sidelined by } \\
\text { foreign wholesale distributors of } \\
\text { the foreign supermarkets } \\
\text { Urban consumers } \\
\text { Retailers }\end{array}$ & $\begin{array}{l}\text { Increased competition from firms and } \\
\text { producers networked with the foreign } \\
\text { supermarkets. } \\
\text { Urban consumers may be left to consuming } \\
\text { poor quality produce as the better quality } \\
\text { produced is exported and quality produce } \\
\text { available locally may be priced out of reach } \\
\text { of the poor urban consumers. }\end{array}$ \\
\hline
\end{tabular}

The emergence of supermarkets is widening the gap between the small producers and large scale commercial farmers due to the inability of small producers to overcome constraints such as quality and quantity requirements in the supermarket chains. There is a general lack of literature and in depth studies focusing on the socio-economic impacts on small producers due to supermarket proliferation in the SADC region. Emongor and Kirsten [12] however provide evidence from Zambia that small producers incomes are better for those participating in supplying supermarkets than those relying only on traditional markets and allude to the fact that small producers are excluded from supermarkets due to procurement processes that are in use by supermarkets. The same study on the one hand also concludes that the presence of supermarkets in Botswana, Zambia and Namibia has not excluded the participation of small scale farmers.

The indirect impacts of increased supermarket activity have also the potential of benefiting the small producers downstream. Barrett el at, [16] have shown that in a study in Mozambique contract farming arrangements were identified to play an important role in integrating smallholder farmers into agricultural value chains. Welfare improvements were noted for smallholder farming households whose participation in contract farming was enabled through membership to farming organisations. An emerging issue to note is the importance of farming organisations in the process of integrating small producers into regional agricultural value chains. This shows that 
cooperative models may present mechanisms through which the increased access to value chains for small producers can be augmented through the ability of the cooperative models to reduce many of the transactions costs that hinder participation of individual small producers and access to supermarket chains.

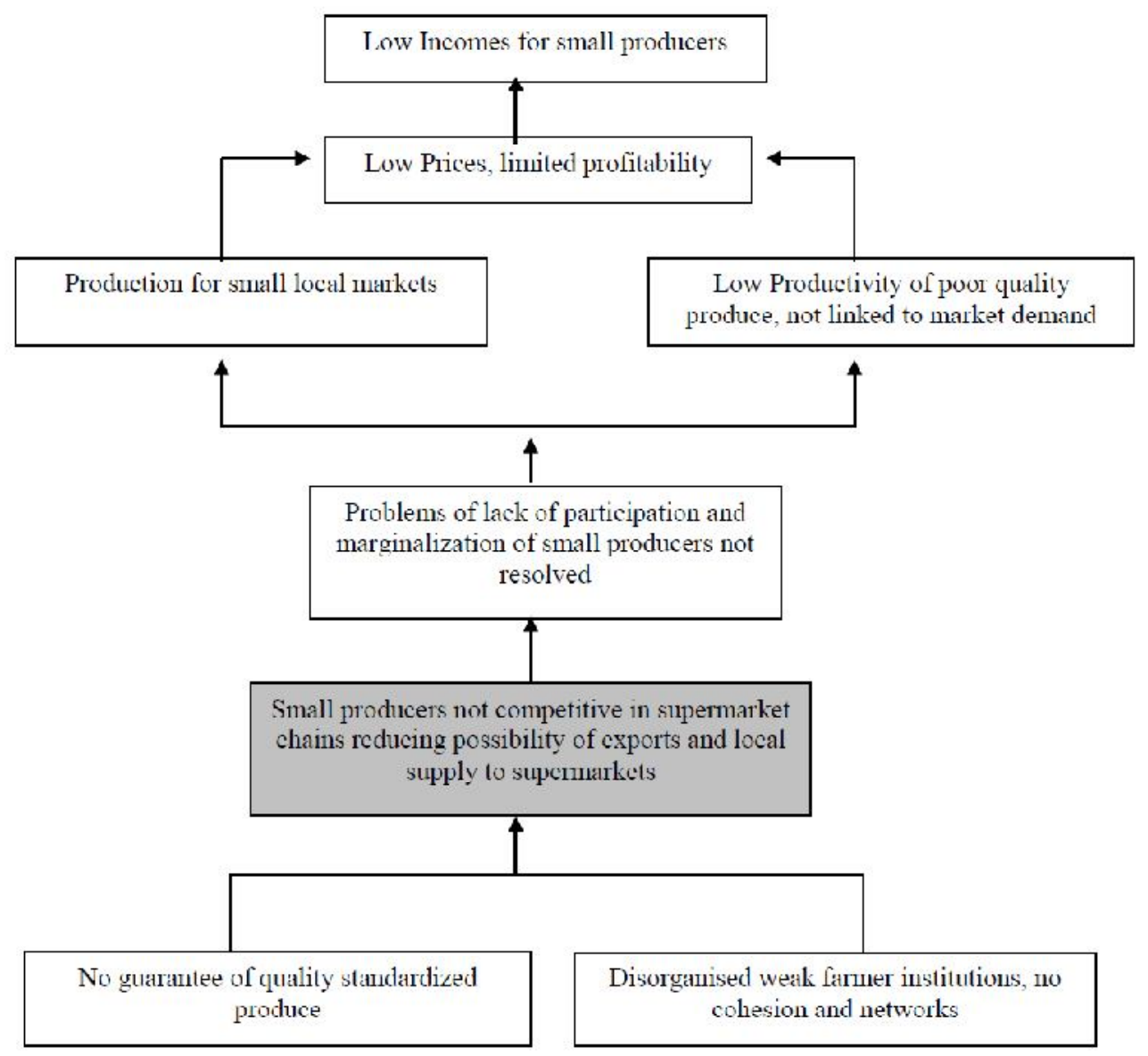

Figure 1. General competitiveness problem of small producers in supermarket chains

\section{Alternatives in Accessing Agricultural Value Chains - A Policy Perspective}

Reflections based on theory as well as the results of some empirical studies show that small producers have forged access to supermarkets with the aid of support agencies and frameworks in place in some countries enabling their participation. Some categories of these initiatives are presented in Table 3. An analysis of investment plans, public policies and partnerships geared specifically to integrate the smallholder farmers in regional markets shows that the focus has to be on involving small producers in creative ways that entail use of appropriate contracts and institutional arrangements that favour small producers' participation in supermarket chains.

Looking ahead and focusing on the problem of small producers failing to meet or guarantee quality standardized output and the general lack of organized networks presented in Figure 1, some key policy factors can be assessed for value chain improvements as presented in Table 3.The facets from a policy factor perspective can be isolated as policy awareness, policy challenges addressed and policy enforcement. Currently, the lack of access to supermarket value 
chains is manifesting in the negative scenario identified in Table 3 for small producers. A positive scenario is desirable and suggested as achievable within the 3 identified facets.

Domestic demand via supermarkets is such that there is an increased demand for value added products on the supermarket shelves. Also relevant is the need for improvement of management systems by small producers inorder to take on value adding responsibilities. Strengthening smallholder production directly improves the conditions for successful participation by small producers in the supermarket chains. Efficient retailing has the potential to reduce costs associated with marketing to the end consumer. There is therefore a need to ensure access to retail possibly through supermarket development and access.

Table 3. Looking Ahead - Key Policy Factors for Value Chain Improvements.

\begin{tabular}{|l|l|l|}
\hline $\begin{array}{l}\text { Key } \\
\text { Factor }\end{array}$ & Policy & Negative Scenario \\
\hline Policy awareness & $\begin{array}{l}\text { Increased awareness at the } \\
\text { level of small producers }\end{array}$ & $\begin{array}{l}\text { Confusion and weak lobbying by } \\
\text { small producers. }\end{array}$ \\
\hline $\begin{array}{l}\text { Policy challenges } \\
\text { addressed }\end{array}$ & $\begin{array}{l}\text { Policies supporting strong } \\
\text { cohesion and networks }\end{array}$ & $\begin{array}{l}\text { Weak farmer institutions and } \\
\text { further marginalization of small } \\
\text { producers }\end{array}$ \\
\hline $\begin{array}{l}\text { Policy } \\
\text { enforcement }\end{array}$ & $\begin{array}{l}\text { Policy enforcement } \\
\text { impacting on vibrancy in the } \\
\text { markets. }\end{array}$ & $\begin{array}{l}\text {-Wrong policies enforced } \\
\text {-Difficulty to implement policies } \\
\text { that have been enforced }\end{array}$ \\
\hline
\end{tabular}

\subsection{Highlighted Cases of Small Producer Inclusion and Value Chain Interventions}

Among a few cases there are reports of a trend towards inclusion of small producers. Other issues that have gained visibility point to the fact that whilst supermarkets like Shoprite may have policies to buy local, this is not the case in Mozambique compared to Zambia. The trend of imports has been perpetuated due to some cited examples of local suppliers not being punctual in deliveries and not being quality conscious. Supermarkets are putting in place mechanisms that allow them to have regular guaranteed volumes. Limited participation by small producers has been a more visible trend in the last four years and some of the factors responsible for thisas depicted in Figure 1. However, some of these shortcomings have not deterred Pick n Pay in opening additional stores in Maputo through partnering with EmVest Group of Companies that has farms already operating in Mozambique. Given a contract as sole provider of Pick n Pay stores in Mozambique, EmVest has tried to be inclusive by coming up with a fresh produce distribution centre that will consolidate produce from other small and large producers. The success of this model however is yet to be tested in terms of whether the small producers will benefit or continue to be marginalized [19]. This however is an indication of how network building can assist in the inclusion of small producers.

Further examples from available literature: [19], [20];[3], are presented in Table 4, highlighting some of the interventions and agribusiness initiatives:

Improving market access has been a focus of development organizations, farming organizations and governments. A call to develop regional agricultural value chains has been made by various organizations like the Economic Commission for Africa and the African Union. These institutions continue to drive or be the forces driving the debate on access to markets by small producers in the SADC region. There is no comprehensive research showing the extent to which the 
programmes in place at regional level have affected the way in which supermarkets view the participation by smallholder farmers.

Cluster development of small scale farmers enabling the coordination of farmers to meet the required quality standards as well as agricultural inputs, skills development and production support have been used as a way to overcome issues of market access to supermarkets. Key initiatives established are joint ventures of local businesses and foreign investors for example outgrower schemes in South Africa, Zambia and Mozambique. The Fair Trade intervention has worked well in Mozambique with the advantage that small producers became successful in gaining Fair Trade accreditation allowing further access to UK supermarkets. The interventions that focus on affordable credit provision have assisted in moving small producers up the value chain ladder, increasing the share of processed products onto the supermarket shelves generating more income in the process.

USAID Regional Agriculture Program boasts of partnerships with international research centers, regional universities and the private sector which have led to increased sales from small holder farmers in targeted cash crops. Figures of over US\$1 million in sales of vegetables, spices and mushrooms have been achieved in a particular reporting period by farmers in Zambia, Malawi and Mozambique through supermarkets, hospitality industry and various processors. It is reported that farmers in response to market demand have increased their hectarages achieving earnings of US\$3500 per month from sales.

The various interventions are a step towards leveling the playing field and act as forces contributing to the inclusion of small producers in the supply chains. The important lessons emanating from observing the trends seems to point to the fact that the more successful initiatives have tended to involve private sector and NGOs usually taking place outside government. Prevalence of meaningful interventions at all stages of the value chains is needed inorder to ensure guaranteed access to supermarkets. Modernised markets and use of commodity trading exchanges is becoming increasingly important and assessing how commodity exchanges can be used in relation to retailing and supermarkets can provide some useful insights for improvements in market access. These observations make clear how important the right mix of policy interventions is for the improved access to markets for small producers. Concrete steps are needed to develop a value chain network that enables the beneficial participation of small producers. The argument in favour of supermarkets is their potential to provide reliable and constant markets for agricultural produce as well as being able to satisfy consumer needs.

\subsection{Regional Policy Options}

A harmonised regional approach to policy formulation aimed at mitigating problems in the value chain has great potential to contribute to efficiency in the agricultural value chains in the SADC region. There is need to identify the policy options that can lead to desirable effects on the "elasticity of poverty reduction" for small producers. Does the answer lie in fostering improvements in the competitive advantage for other nationsinorder that they can also provide FDI in supermarket chains...is this possible at all because South Africa has the comparative advantage which leads to its dominance. The disconnection of local/national industrial policies and regional aspirations further complicate the augmenting of benefits that can be gained from regional agricultural value chains. The private sector is not working with the SADC institutions, operations and structures. Regional pricing mechanisms need to be developed in line with the development of supply chain networks into the region. 
Table 4.Value Chains Interventions in Selected Countries.

\begin{tabular}{|c|c|c|}
\hline Country & $\begin{array}{l}\text { Examples of Value Chain } \\
\text { Interventions }\end{array}$ & Benefits/Advantages \\
\hline South Africa & $\begin{array}{l}\text { Agri-franchising- turn-key } \\
\text { cluster development of a } \\
\text { group of emerging farmers } \\
\text { Alice South Africa - An } \\
\text { outgrower scheme - } \\
\text { vegetable producer group } \\
\text { supplying } \\
\text { domesticsupermarkets }\end{array}$ & $\begin{array}{l}\text { Improved position of farmers in } \\
\text { negotiating } \\
\text { competencies related to value chains } \\
\text { supply and enhancing understanding } \\
\text { of the needs of the supermarkets to } \\
\text { satisfy consumer demand. Standards } \\
\text { certification }\end{array}$ \\
\hline Mozambique & $\begin{array}{l}\text { EmVest } \\
\text { Companies }\end{array} \quad$ Group of & $\begin{array}{l}\text { Involve Mozambican small } \\
\text { producers without compromising on } \\
\text { quality, setting up small scale } \\
\text { cooperatives that will collect and } \\
\text { redistribute local produce into } \\
\text { EmVest distribution centre. The } \\
\text { initiative is coupled with a technical } \\
\text { and financial training component for } \\
\text { small producers. }\end{array}$ \\
\hline $\begin{array}{l}\text { South Africa, Zambia, } \\
\text { Ghana, Rwanda, } \\
\text { Senegal }\end{array}$ & $\begin{array}{l}\text { ASNAPP (Agribusiness in } \\
\text { Sustainable Natural African } \\
\text { Plant Products) }\end{array}$ & $\begin{array}{l}\text { Advocate for market-first approach } \\
\text { focusing on retail (has linked farmers } \\
\text { to Shoprite and Spar Supermarkets }\end{array}$ \\
\hline $\begin{array}{l}\text { Ethiopia, Kenya, } \\
\text { Mozambique, } \\
\text { Rwanda, Sudan, } \\
\text { Tanzania, Uganda, } \\
\text { Zambia, Zimbabwe }\end{array}$ & $\begin{array}{l}\text { Netherlands Development } \\
\text { Organisation, SNV }\end{array}$ & $\begin{array}{l}\text { Support for business organizations } \\
\text { and their access to markets }\end{array}$ \\
\hline Mozambique & $\begin{array}{l}\text { Fair Trade, example } \\
\text { Cheetah Mozambique } \\
\text { Government Project for } \\
\text { Entrepreneurial } \\
\text { Development }\end{array}$ & $\begin{array}{l}\text { Linkage promotion projects to enter } \\
\text { supply chains }\end{array}$ \\
\hline
\end{tabular}

There is need to consider how the governance issues in value chains can be impacted upon through regional policy that deliberately targets small producers' participation in supermarket chains. There are however some important questions that could improve the way interventions will be targeted and by characterizing the small producers and considering their assets, asking at what point should the interventions be. Considering issues of how smallholder farmers can access markets, the identified enabling and coping factors may be institutionalized within a regional policy framework with the following expected policy implications:

Enabling Factors --------- $\rightarrow$ Enabling participation by small producers. Require coordination of market, transactions costs reduced, role of support organizations.

Coping Factors --------- $\rightarrow$ Assist producers to cope and minimize the negative socio-economic impacts as a result of marginalization from supermarket value chains. Require competition laws, farm sector policies. 
International Journal of Managing Value and Supply Chains (IJMVSC) Vol.4, No. 3, September 2013

\section{Summary of Findings, Analysis And Suggested Policy Options}

New trends in supermarket chain participation have emerged to include improved and better organization of farmers to take advantage of available markets. At the same time new arrangements have been tested. These trends speak to the need to undertake rigorous and more vigilant approaches to create enabling environments for the successful participation of small producers.

This paper has highlighted that access to supermarkets is necessary for small producers to ensure their livelihoods. With the proliferation of supermarkets small producers have lost their traditional market share as they are unable to compete in satisfying the consumer.The supermarket chains are focused on organization throughout the value chain resulting in handpicking of participants supplying supermarket chains.Small producers do not only face competition from the large producers in their country but have to face competition from outside their own borders.

However, whilst efforts are being made to ensure the inclusion of small producers as supermarkets proliferate it has been recognized that:- Unless there are deliberate interventions to address small producers constraints, the gap will widen between small producers and large producers as the trend is likely to continue with supermarkets oriented to doing business within a network that satisfies their requirements, whilst small producers continue to be marginalized. There is need to distinguish whether the foreign supermarkets are buying locally out of pressure from local suppliers and national policies in place or that there is indeed a benefit in buying locally. Innovativeness and testing of new approaches to engaging small producers is imperative and so is assessing if the best model is in place for engagement of small producers.

\section{REFERENCES}

[1] CRUSH, J. and FRAYNE, B., 2011. Supermarket Expansion and the Informal Food Economy in Southern African Cities: Implications for Urban Food Security. Journal of Southern African Studies, 37(4), pp. 781-807.

[2] NEVEN, D., REARDON, T., CHEGE, J. and WANG, H., 2006. Supermarkets and Consumers in Africa. Journal of International Food \& Agribusiness Marketing, 18(1-2), pp. 103-123.

[3] ABRAHAMS, C., 2010. Transforming the region: supermarkets and the local food economy. African Affairs, 109(434), pp. 115-134.

[4] LOUW, A., VERMEULEN, H., KIRSTEN, J. and MADEVU1 , H., 2007. Securing small farmer participation in supermarket supply chains in South Africa. Development Southern Africa, 24(4), pp. 539-551.

[5] TEMU, A.E. and TEMU, A.A., 2005. High value agricultural products for smallholder markets in Sub-Saharan Africa: trends, opportunities and research priorities, Prepared for an international workshop, "How Can the Poor Benefit from the Growing Markets for High Value Agricultural Products 2005, pp. 3-5.

[6] LOUW, A., JORDAAN, D., NDANGA, L. and KIRSTEN, J.F., 2008. Alternative marketing options for small-scale farmers in the wake of changing agri-food supply chains in South Africa. Agrekon, 47(3), pp. 287-308.

[7] VINK, N., MCCARTHY, C., SANDREY, R. and ZUNCKEL, H., 2006. Promoting agricultural trade and investment synergies between South Africa and other SADC Member countries Tralac Working Paper No. 20," US Printers, Stellenbosch.

[8] DAKORA, E.A., Exploring the fourth wave of supermarket evolution: concepts of value and complexity in Africa. International Journal of Managing Value and Supply Chains, 3(2), pp. 25-37

[9] ORTMANN, G.F. and KING, R.P., 2010. Research on agri-food supply chains in Southern Africa involving small-scale farmers: Current status and future possibilities. Agrekon, 49(4), pp. 397-417.

[10] BAHIIGWA, G., 2006. Access of Eastern African Farmers to Domestic and International Markets: Opportunities and Constraints, Invited paper prepared for presentation at the International Association of Agricultural Economists Conference 2006. 
[11] MINTEN, B. and REARDON, T., 2008. Food prices, quality, and quality's pricing in supermarkets versus traditional markets in developing countries. Applied Economic Perspectives and Policy, 30(3), pp. $480-490$.

[12] EMONGOR, R. and KIRSTEN, J., 2009. The impact of South African supermarkets on agricultural development in the SADC: a case study in Zambia, Namibia and Botswana. Agrekon, 48(1), pp. 6084.

[13] SHOPRITE, 2012. Annual Report, World Wide Web. Available at www.shoprite.co.za [Accessed March 14, 2013]

[14] PICK n PAY, 2012. Annual Report, World Wide Web. Available at www.http://www.picknpayir.co.za/financials/annual_reports/2012/index.php [Accessed March 14, 2013]

[15] BOSELIE, D., HENSON, S. and WEATHERSPOON, D., 2003. Supermarket procurement practices in developing countries: Redefining the roles of the public and private sectors. American Journal of Agricultural Economics, 85(5), pp. 1155-1161.

[16] BARRETT, C.B., BACHKE, M.E., BELlEMARE, M.F., MICHELSON, H.C., NARAYANAN, S. and WALKER, T.F., 2012. Smallholder Participation in Contract Farming: Comparative Evidence from Five Countries. World Development, 40(4), pp. 715-730.

[17] POSTHUMUS, H., 2010. Linking Smallholders To Markets: Lessons Learned From Past Projects And Implications For Cassava: Adding Value for Africa. Brief no. 2: Linking smallholders to markets, March 2010. Natural Resources Institute. University of Greenwich, UK

[18] HICHAAMBWA, M. and TSCHIRLEY, D., 2006. Understanding Zambia's Domestic Value Chains for Fresh Fruits and Vegetables. Policy Synthesis: Food Security Research Project-Zambia, .

[19] EmVest GROUP OF COMPANIES, 2012. World Wide Web. Available at http://www.emvest.com/Emvest_EDS.html [Accessed January 4, 2013]

[20] NISHIURA, A., 2010. The Food Industry and Supermarkets in Eastern Africa: A preliminary report on research in Tanzania and Ethiopia.In Fukunishi (ed) African Producers in the New Trend of Globalisation: An Interim Report, Chosakenyu Hokokusho, Institute of Developing Economies, 2010 